\title{
Ethanol influence on gingival fibroblasts - a real-time in vitro study
}

\author{
Marzena Wyganowska-Świątkowska ${ }^{1, A, C-D, F}$, Agnieszka Nowak ${ }^{2, B-C}$, Elżbieta Paszyńska ${ }^{3, E}$, \\ Kinga Grzech-Lesniak ${ }^{4, D}$ \\ ${ }^{1}$ Department of Conservative Dentistry and Periodontology, University of Medical Sciences, Poznan, Poland \\ 2 University of Life Sciences, Poznan, Poland \\ ${ }^{3}$ University of Medical Sciences, Poznan, Poland \\ ${ }^{4}$ Medical University, Wroclaw, Poland \\ A - Research concept and design, B - Collection and/or assembly of data, C - Data analysis and interpretation, \\ $D$ - Writing the article, E-Critical revision of the article, F - Final approval of article
}

\begin{abstract}
Wyganowska-Świątkowska M, Nowak A, Paszyńska E, Grzech-Lesniak K. Ethanol influence on gingival fibroblasts -a real-time in vitro study. Ann Agric Environ Med. 2018; 25(4): 647-650. doi: 10.26444/aaem/78696
\end{abstract}

\section{Abstract}

Introduction. Alcohol consumption is the world's third largest risk factor for disease and disability. According to the WHO report from 2011: 71\% of urban respondents ty and 77\% of rural respondents admit to alcohol consumption]. Lower socio-economic status and educational levels result in a greater risk of alcohol-related injury, disease and death. Alcohol is a common component of many medicines, as well as an ingredient in many oral hygiene home products. Mouthwashes containing alcohol are considered to inhibit wound healing in the oral cavity. Due to the fact that many different results are described for different concentrations of alcohol at different times, an attemptwas made to visualise the direct impact of $7.2 \%$ and $22 \%$ alcohol on human gingival fibroblasts.

Materials and method. PANsystem 2000 was used for visualisation of the reaction of human gingival fibroblasts isolated from gingiva on ethanol in 2 different concentrations. PANsys 3000 is a multi-system fully-automated cell culture device used for in vitro culture and to study a variety of cell lines under conditions similar to in vivo. Observations were carried out for 48 hours since alcohol addition. Pictures were taken in a continuous process at 5 minute intervalds and combined into a film.

Results. Both contamination of $7.2 \%$ and $22 \%$ ethyl alcohol negatively affected morphology and cell proliferation. Addition of ethanol at a concentration $7.2 \%$ enabled cells to regain their ability to divide and recover normal morphology after 10 hours; changes caused by $22 \%$ ethanol, however, were irreversible.

Conclusions. The obtained results suggest that daily usage of $7.2 \%$ alcohol contained in mouthwashes is non-toxic for gingival fibroblasts, and could be recommended after periodontal surgery.

\section{Key words}

alcohol, oral cavity, gingival fibroblasts

\section{INTRODUCTION}

Alcohol consumption is the world's third largest risk factor for disease and disability, revealing the greatest risk in middle-income countries [1]. According to a WHO report (2011), over $70 \%$ of the urban and rural populations admit to alcohol consumption [2]. Lower socio-economic status and educational level result in a greater risk of alcohol-related injury, disease and death. Ethyl alcohol is a causal factor in 60 types of diseases and injuries, and a component cause in 200 others [1].

Ethanol is also a common component of many medicines prescribed from very early childhood, as well as an ingredient in many oral hygiene home products. The oral cavity is the first part of the digestive tract, which has contact with high- and low-concentrated alcohol. It can also be affected by ethanol metabolites [3]. Alcohol-based mouthwashes remain in longer contact with the oral cavity than alcoholic beverages when an alcoholic beverage is ingested. It has

Address for correspondence: Marzena Wyganowska-Swiatkowska, Department of Conservative Dentistry and Periodontology, University of Medical Sciences, Bukowska 70, 60-812 Poznan, Poland

E-mail: marzena.wyganowska@periona.pl

Received: 16.05.2017; accepted: 17.10.2017; first published: 15.11.2017 been suggested that the use of alcohol-based mouthwashes may exhibit genotoxic effects [5], increase the risk for oral cancer [4], decrease host defence and is one of the stressors [6]. Additionally, the adverse effect of ethyl alcohol on oral tissue and structures have been observed. These include mouth burning, drying of mucosa [7], and softening effect on composite materials [8]. According to the American Dental Association (ADA) and Food and Drug Administration (FDA), the alcohol concentration in products for medical use cannot exceed 5.0\% [9] in the case of formulas applied in children. The commercially-available mouthwashes contain $7-25 \%$ of alcohol [10]. As found, a concentration of ethyl alcohol exceeding 5\% inhibits proliferation of fibroblasts in 24-h culture, and transforming growth factor - TGF $\beta$ induced collagen synthesis [11]. Interestingly, acute alcohol exposure induces TGF release from monocytes, an effect which might itself be expected to accelerate wound healing [12], but it was indicated that an increased level of TGF $\beta$ had no additional local effect on healing after alcohol exposure [10]. Ethanol can also stimulate proliferation of gastrointestinal mucosa [13] and astrocytes in an in vitro experimental model [14]. As found in a previous study by the authors, the morphology of human fibroblasts did not differ substantially from control cells when exposed in vitro 
to $10 \%$ alcohol for $48 \mathrm{~h}$. Moreover, the increase in the number of cells was lower than in the control group, although the difference was not statistically significant. Isolated necrotic cells were observed [15].

The most effective mouthwashes contain chlorhexidine (CHX) or essential oils (EO). $0.1 \%$ CHX contains $7.2 \%$ ethanol, whereas EO contains $22 \%$ ethyl alcohol. The presence of ethanol in a mouth rinse containing $0.10 \%$ chlorhexidine has no deleterious effects on healing capacity; on the contrary, it helps stimulate wound healing. The combination of chlorhexidine plus ethanol is superior for healing. It is suggested that ethyl alcohol added to chlorhexidine decrease chlorhexidine cytotoxity [16]. However in many cell-based experimental models, ethanol has been found to inhibit the effects of growth factors, including insulin and insulinlike growth factor $[17,18]$. The growth- inhibitory effects of ethanol are often accompanied by increased apoptotic cell death $[19,20]$.

Due to the fact that many different results have been described for different concentrations of alcohol at different times, an attempt was made to visualise the direct impact of $7.2 \%$ and $22 \%$ ethanol on human gingival fibroblasts. For this purpose, a fully automated multi-system cell culture devised. This allowed observation of the impact of ethanol on human fibroblasts in conditions most similar to in vivo, and allow a longer time without intervals.

\section{MATERIALS AND METHOD}

PANsys 3000 (Systech GmbH, Augsburg, Germany) was used for the experiment. This is a multi-system fully automated cell culture device used for in vitro culture and for studying a variety of cell lines under conditions similar to in vivo. The system allows for the culturing of various cells and the use of various compositions of the media at the same time, using any culture conditions and a selected microscopic observation. All data associated with the experiments can be recorded and played back at a later time.

In order to perform the experiment, human fibroblast cells were isolated from gingival tissue obtained from 5 patients during the standard protocol of recession, and cultured in flasks with surface of $25 \mathrm{~cm}^{2}$ in DMEM (Dulbecco's Modified Eagle's Medium) supplemented with 10\% FBS (Foetal Bovine Serum) and $1 \%$ antibiotic-antimycotic solution (10,000 units penicillin, $10 \mathrm{mg}$ streptomycin and $25 \mu \mathrm{g}$ amphotericin $\mathrm{B}$ per $\mathrm{ml}$ ) at $37^{\circ} \mathrm{C}$ with $5 \% \mathrm{CO}_{2}$ concentration. The cell cultures with $70-80 \%$ confluence were washed with $3 \mathrm{ml}$ of Hanks solution and trypsinized (0.25\% trypsin, $0.02 \%$ EDTA). Cells were gathered by centrifugation (1,000 rpm, $10 \mathrm{~min}) .500 \mathrm{ml}$ of the cell suspension after trypsinization was combined with $500 \mathrm{ml}$ of culture medium, supplemented with $10 \%$ FBS and $1 \%$ antibiotic-antimycotic solution, and placed in a growth chamber device PANsys 3000 - a multi-system fullyautomated cell culture device used for in vitro culture and for studying a variety of cell lines under conditions similar to in vivo. The cells were cultured for $24 \mathrm{~h}$ at $37^{\circ} \mathrm{C}$ with $5 \%$ $\mathrm{CO}_{2}$ concentration. After $24 \mathrm{~h}$ of culturing, $250 \mathrm{ml}$ of ethyl alcohol (7.2\% and 22\%) was added to each chamber:

Chamber $1-7.2 \%$ ethanol in DMEM solution;

Chamber 2 - 22\% ethanol in DMEM solution;

Chamber 3 - control sample: full DMEM, no addition of ethanol.

All reagents were obtained from MERCK, Life Science Department, Poland.

Observations were carried out for $48 \mathrm{~h}$ after alcohol addition. Images were performed in a continuous process at $5 \mathrm{~min}$ intervals and combined into a movie. Images related to a specific region in the chamber - the same region (Region of Interest) and photographed for $72 \mathrm{~h}$ from the moment of placing cell solutions in the chambers $-24 \mathrm{~h}$, and then after adding ethyl alcohol to the culture $-48 \mathrm{~h}$.

All experiments were performed 3 times for each patient's cells. All results were similar. Results from a representative experiment are shown below.

\section{RESULTS}

As a result of carrying out $48 \mathrm{~h}$ of cell culture in DMEM solution containing alcohol at a concentration of 7.2 and $22 \%$, changes were observed in morphology and cell division in both cell lines.

Immediately after the addition of alcohol at the concentration of $7.2 \%$, changes in cell proliferation and cell morphology were observed, in comparison to the control (Fig. 1) (http://marzena.softweb.pl/control.avi; password wyga1302). Decrease in growth rate and the number of cell divisions was observed, resulting in a constant number of cells in the observed region. The cells were also morphologically changed: size was significantly reduced and shape was changed (from spindle to irregular) (Fig. 2). 10 hours after alcohol addition, the cells returned to their normal, regular shape and started again the regular dividing processes (http:// marzena.softweb.pl/ethanol7_2.avi; password wyga1302).

Immediately after the addition of alcohol at the concentration of $22 \%$, significant changes in cell proliferation and cell morphology were observed, in comparison to the control. The cells were also morphologically changed: size significantly reduced and shape changed (from spindle to irregular). After addition of the alcohol to the culture
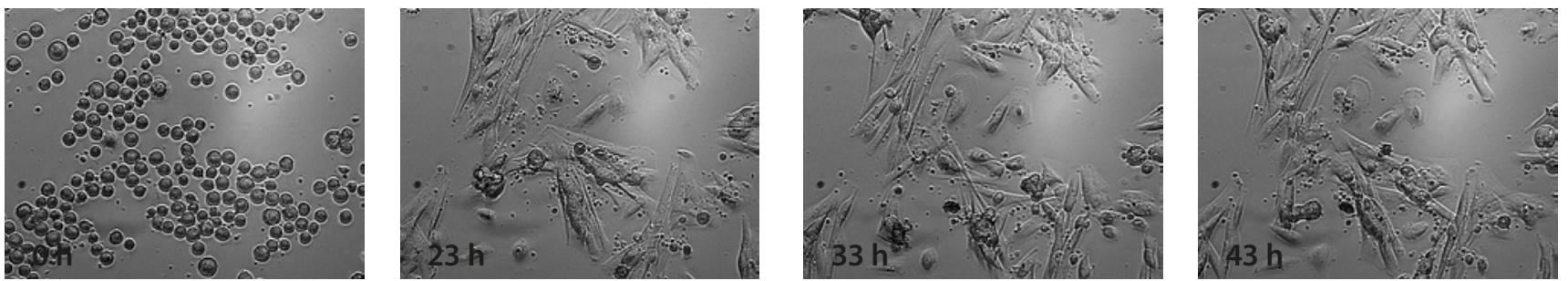

Figure 1. Representative images acquired using the Pansys 3000 system showing human gingival fibroblasts during $48 \mathrm{~h}$ of observation following stimulation. The fibroblasts were cultured with DMEM medium supplemented with $10 \% \mathrm{FBS}$ and $1 \%$ antibiotic-antimycotic solution. The fibroblasts had a normal prolonged shape with projections during the whole culturing process 

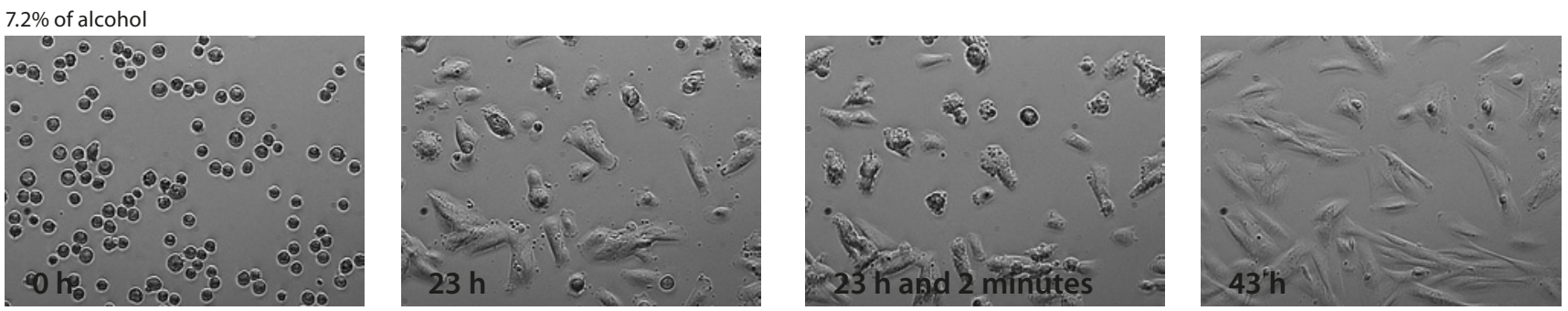

Figure 2. Representative images acquired using the Pansys 3000 system showing the effects of alcohol on human gingival fibroblasts during $48 \mathrm{~h}$ of observation following stimulation. Some of the fibroblasts treated with alcohol at a concentration of $7,2 \%$ had an oval appearance with no filopodia; some of them had an irregular shape. $10 \mathrm{~h}$ after alcohol addition, the cells returned to their normal, regular shape.

$0 \mathrm{~h}$ - beginning of culturing; $23 \mathrm{~h}-2 \mathrm{~min}$. before alcohol addition; $23 \mathrm{~h}$ and $2 \mathrm{~min}$. $-2 \mathrm{~min}$. after alcohol addition; $43 \mathrm{~h}-20 \mathrm{~h}$ after alcohol addition
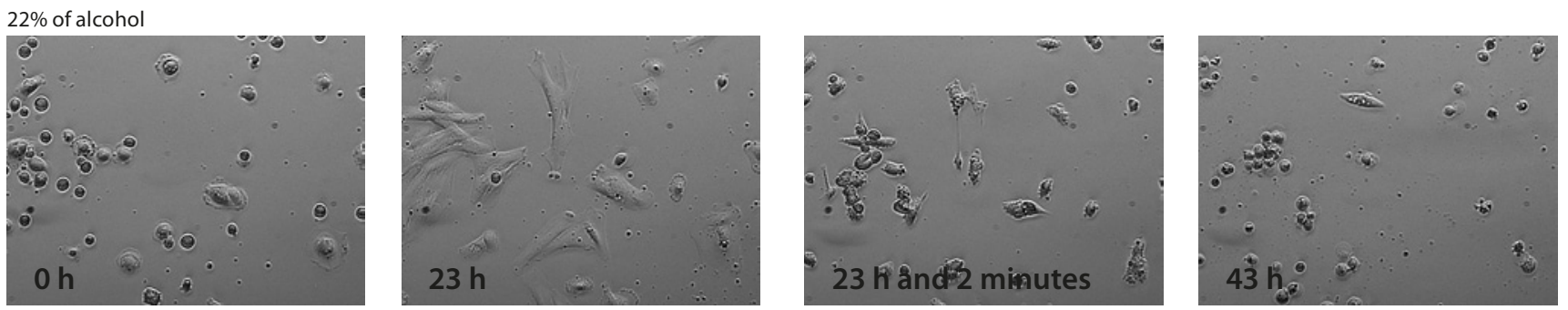

Figure 3. Representative images acquired using the Pansys 3000 system showing the effects of alcohol on human gingival fibroblasts during $48 \mathrm{~h}$ of observation following stimulation. The fibroblasts treated with alcohol at a concentration of $22 \%$ were small in number and had an oval appearance with no filopodia.

$0 \mathrm{~h}$ - beginning of culturing; $23 \mathrm{~h}-2$ minutes before alcohol addition; $23 \mathrm{~h}$ and 2 minutes $-2 \mathrm{~min}$. after alcohol addition, $43 \mathrm{~h}-20 \mathrm{hours}$ after alcohol addition)

medium, the cells were incubated in a hypertonic solution, cells lost water so that cytoplasm became very thick and cell volume was significantly decreased. There was also complete inhibition of cell division. After 6 hours from the addition of alcohol, cells completely lost their ability to divide and took a spherical shape. There were no visible movements of the cytoplasm. A very visible effect of the addition of alcohol was also the immediate loss of cell projections (Fig. 3; $23 \mathrm{~h}$ and 2 minutes), which in turn made it impossible to connect to the fibroblast colony and thereby further divisions (http:// marzena.softweb.pl/ethanol22.avi; password wyga1302).

Ethanol causes the off-state of normal operations and weakening of the cell. After the resignation of poisoning, the cell regains its previous efficiency (which is noticeable in the case of $7.2 \%$ ethyl alcohol addition), but if poisoning lasts longer, the function of the cell is permanently weakened or irreversibly disappears.

\section{DISCUSSION}

The observation let us to conclude that both the contamination with $7.2 \%$ and $22 \%$ ethyl alcohol negatively affects morphology and cell proliferation. The addition of ethanol at a concentration $7.2 \%$ enables cells to regain their ability to divide and recover normal morphology after $10 \mathrm{~h}$, when changes caused by $22 \%$ ethanol are irreversible.

Alcohol consumption may be considered as a risk indicator for periodontitis [21]. There are several potentially important local mechanisms by which alcohol can interfere with fibroblasts. One of local mechanism by which alcohol can interfere with fibroblasts in the wound-healing process in maxillofacial injuries is the inhibition of fibroblast proliferation and ECM synthesis at the wound site [22]. Alcohol significantly reduced cell viability and increased reactive oxygen species in oral fibroblasts [6]. In animal models, alcohol consumption increased gingival oxidative damage and the production of TNF- $\alpha$ in periodontal ligament fibroblasts [23]. Decreasing cell viability in response to increasing alcohol concentration was dosedependent. Alcohol can decrease host defence in oral cavity tissue by altering cytokine production and lymphocyte $\mathrm{T}$ function [11]. In another in vitro study, alcohol negatively influenced fibroblast growth factor-mediated aortic smooth muscle cell proliferation by reducing phosphorylation of downstream kinases, and disrupting the cell cycle regulation [24]. Fibroblast cells isolated from trauma patients caused impairments in re-epithelialisation, angiogenesis, and inflammation in wounds following acute alcohol exposure [25]. It has been suggested that the cytotoxity of alcohol depends the on concentration and how long the mouthwash was retained in the mouth [26].

Alcohol on its own causes damage to the oral mucosa and includes epithelial atrophy and decease in basal cell size atrophy with associated hyper-regeneration [27]. However, a cytological study performed by Bagan et al. [28] revealed no changes in epithelial superficial, intermediate, parabasal, or basal cells in samples collected from patients who had regularly been using mouthwash containing $26 \%$ alcohol for 6 months.

In the presented study, a very similar method for in vivo conditions was used for cell behaviour observation. The reaction of fibroblasts after $7.2 \%$ alcohol stimulation was probably connected with the difference of concentration between the xternal environment and cell cytoplasm. The hydrophilic nature of alcohol renders its easy distribution to every tissue containing water. It is also possible that the difference obtained in the current study is due to only a single dose of alcohol. Ethanol has easily detectable promitogenic effects only when added to the cells only once, without sealing the wells [29]. It has been shown that ethanol can bind, although weakly, to certain proteins in various membranes which become saturable for it $[30,31]$. This could probably explain the non-toxic or even stimulatory effect 
of ethanol when combined with other active ingredients in medicines [32].

The present study shows that the applied system is convenient for monitoring the reaction of cells to different agents. However there are some limitations to the study. First of all, trypsinization influences the cells vitality. The visualization of fibroblasts reaction on ethanol, although performed in conditions most similar to in vivo, is still far from a real in vivo situation. In a real in vivo situation it is difficult to exclude the influence of ethanol metabolite products on cells during ethyl alcohol consumption.

\section{CONCLUSION}

The real-time in vitro study is a convenient model to observe and record cells in reaction to various agents, such as ethanol. This is the first time that the reversible effect of $7.2 \%$ alcohol on gingival fibroblasts viability has been visualized. These results suggest that the daily use of mouthwashes containing $7.2 \%$ alcohol is non-toxic for gingival fibroblasts, and can be recommended after periodontal surgery.

\section{Acknowledgements}

The study was supported by the University of Medical Sciences in Poznan, Poland.

\section{REFERENCES}

1. Petersen PE. Strengthening the prevention of oral cancer: the WHO perspective. Community Dentistry Oral Epidemiology 2005; 33: 397-399.

2. Global status report on alcohol and health. WHO Press Geneva, 2011.

3. Moritani K, Takeshita T, Shibata Y, Ninomiya T, Kiyohara Y, Yamashita Y. Acetaldehyde production by major oral microbes. Oral Dis. 2015; 21: 748-754.

4. McCullough MJ, Farah CS. The role of alcohol in oral carcinogenesis with particular reference to alcohol-containing mouthwashes. Australian Dent J. 2008; 53: 302-305.

5. Carlin V, Matsumoto MA, Saraiva PP, Artioli A, Oshima CT, Ribeiro DA. Cytogenetic damage induced by mouthrinses formulations in vivo and in vitro. Clin Oral Invest. 2012; 16: 813-820.

6. San Miguel SM, Opperman LA, Allen EP, Zielinski J, Kathy KH. Bioactive polyphenol antioxidants protect oral fibroblasts from ROSinducing agents. Arch Oral Med. 2012; 57: 1657-1667.

7. Chevalier M, Sakarovitch C, Precheur I, Lamure J, Pouyssegur-Rougier V. Antiseptic mouthwashes could worsen xerostomia in patients taking polypharmacy. Acta Odontol Scand. 2015; 73: 267-273.

8. Gagari E, Kabani S. Adverse effects of mouthwash use. Oral Surgery Oral Medicine Oral Pathology Oral Radiology Endodontics. 1995; 80: 432-439.

9. Shulman JD, Well LM. Acute ethanol toxicity from ingesting mouthwash in children younger than 6-years of age. Pediatric Dentistry. 1997; 19: 404-408.

10. Addy M. Oral hygiene products: potential for harm to oral and systemic health?. Periodontology 2000. 2008; 48: 54-65.

11. Stephens P, al-Khateeb T, Davies KJ, Shepherd JP, Thomas DW. An investigation of the interaction between alcohol and fibroblasts in wound healing. Int J Oral Maxillofacial Surg. 1996; 25: 161-164.
12. Szabo J, Bikash VK, Fogarasi M, Cata-Lano DE. Induction of transforming growth factor-beta and prostaglandin E2 production by monocytes. J Leukocyte Biol. 1992; 52: 602-610.

13. Simanowski UA, Stickel F, Maier H, Gartner U, Seitz HK. Effect of alcohol on gastrointestinal cell regeneration as a possible mechanism in alcohol-associated carcinogenesis. Alcohol, 1995; 12: 111-115.

14. Aroor A, Baker RC. Negative and positive regulation of astrocyte DNA synthesis by ethanol. J Neurosci Res. 1997; 50: 1010-1017.

15. Wyganowska-Swiatkowska M, Urbaniak P, Szkaradkiewicz A, Jankun J, Kotwicka M. Effects of chlorhexidine, essential oils and herbal medicines (Salvia, Chamomile, Calendule) on human fibroblast in vitro. Centr Eur J Immunol. 2016; 41: 1-7.

16. Boisnic S, Ben Slama L, Branchet-Gumila MC, Watts M, D’Arros G.Wound healing effect of Eludril in a model of human gingival mucosa. Revue Stomatologie Chirurgie Maxillo-faciale. 2006; 107: 431-435.

17. Luo J, Miller MW. Ethanol inhibits basic fibroblast growth factormediated proliferation of C6 astrocytoma cells. J Neurochem. 1996; 67:1448-1456

18. Luo J, Miller MW. Growth factor-mediated neural proliferation: Target of ethanol toxicity. Brain Res Rev. 1998; 27: 157-167.

19. Luo J, West JR, Pantazis NJ. Nerve growth factor and basic fibroblast growth factor protect rat cerebellar granule cells in culture against ethanol-induced cell death. Alcohol Clin Experimental Res. 1997; 21: 1108-1120.

20. Cartwright MM, Tessmer LL, Smith SM. Ethanol-in- duced neural crest apoptosis is coincident with their endog- enous death, but is mechanistically distinct. Clin Experimental Res. 1998; 22:142-149.

21. Shepherd S. Alcohol consumption a risk factor for periodontal disease. Evidence-Based Dentistry. 2011; 12: 76.

22. Hendriks T, Martens MFWC, Huyben CMLC, Wobbes T. Inhibition of basal and TGF-B induced fibroblast collagen synthesis by antineoplastic agents. Implications for wound healing. British J Cancer. 1993; 67: 545-50.

23. Irie K, Tomofuji T, Tamaki N, Sanbe T, Ekuni D, Azuma T, et al. Effects of ethanol consumption on periodontal inflammation in rats. J Dental Res. 2008; 87: 456-60.

24. Amaral Cda S, Vettore MV, Lea o A. The relationship of alcohol dependence and alcohol consumption with periodontitis: a systematic review. J Dentistry. 2009; 37: 643-651.

25. Ranzer MJ. Fibroblast function and wound breaking strength is impaired by acute ethanol intoxication. Alcohol Clin Exper Res. 20011; 35: 83-90.

26. Guha N, Boffetta P, Wünsch V, Eluf Neto J, Shangina O, Zaridze D, et al. Oral health and risk of squamous cell carcinoma of the head and neck and esophagus: results of two multicentric case-control studies. Am J Epidemiol. 2007; 166: 1159-1173.

27. Howie NM, Trigkas TK, Cruchley AT, Wertz PW, Squier CA, Williams DM. Short term exposure to alcohol increases the permeability of human oral mucosa. Oral Dis. 2001; 7: 340-354.

28. Bagan JV, Vera-Sempere F, Marzal C, Pellín-Carcelén A, Martí-Bonmatí E, Bagan L. Cytological changes in the oral mucosa after use of a mouth rinse with alcohol: A prospective double blind control study. Medicina Oral Patologia Oral Cirurgia Bucal. 2012; 17: e956-961.

29. Huang JS, She QB, Crilly KS, Kiss Z. Ethanol, Zn2+ and insulin interact asprogression factors to enhance DNA synthesis synergistically in the presence of $\mathrm{Ca} 2+$ and other cell cycle initiators in fibroblasts. Biochem J. 2000; 346: 241-247.

30. Li C, Peoples R, Weight FF. Alcohol action on a neuronal membrane receptor: Evidence for a direct interaction with the receptor protein. Proceedings National Academy Science USA. 1994; 19: 8200 -8204.

31. Channareddy S, Nguyen NT, Janes N. Saturable ethanol binding in rat liver mitochondria. Biochimica Biophysica Acta. 2000; 1463: 291-300.

32. Crilly KS, Benyhe S, Kiss Z. Promitogenic effects of ethanol, methanol, and ethanolamine in insulin-treated fibroblasts. Biochem Pharmacol. 2000; 60: 1391-1398. 